\title{
The Development of Children Attire in Malay Ceremonials in the Context of Malay Socio-Cultural
}

\author{
Arba'iyah binti Ab. Aziz, Mohamad Kamal bin Abd Aziz, Nabilah binti Mudzafar, \\ Nor Idayu binti Ibrahim
}

\begin{abstract}
Basically this research is a part of Malay historical research that emphasize on the significance and the beauty of Malay culture. This research is focuses on the Malay children attire in specific ceremonies. Culture is the common way of life of a community or a nationhood that manifest the ideas, custom and social behavior collectively. The cultural activist has divided the human aspect of life into various field. It involves the arts, custom, social habits, economy, language, attires and accessories, courtesy, value system, and neighborhoods. In general culture can be defined as an instruction to the members of a society in a closer way of life (Asmad, 1990). Meanwhile, Zubaidah Sual (2017) has stated that, the annotation of Malay traditional clothe is the style worn by the communal during the specific ceremonies and their daily style. Therefore, this historical research is relatively based on the Mayer Schapiro theory of style in analysing the artefacts. As mentioned by Siti Zainon Ismail (2016), there are two level of Malay cultural manifestation which are; 'tradisi agung' and 'tradisi rakyat' or the royal and the communal. This research aims to explore on the style and the material use in each of these children attires. Furthermore, it discusses the children customary clothes in three main ceremonies namely head shaving ceremony/ cukur jambul, circumcised / berkhatan, and also baby ear piercing / bertindik. In a nutshell, these two different group of Malay tradition maintain the Malay traditional attire style in each of their ceremony. Yet the royals are keen to use Songket and beautiful lavish accessories meanwhile the communal are constantly keep to use the economical materials for their children ceremonial attires. Overall, this study will provide an invaluable source of information about Malay custom and culture. It will be benefited to the Malay royal families, researchers, academicians, scholars, students, cultural archivists, museum curators and public at large in studying and preserving this heritage and tradition.
\end{abstract}

Keywords: Children Customary Clothing, Baby Head-shaving, Circumcised, Baby Ear-piercing.

\section{INTRODUCTION}

This research paper is discuss on the children ceremonial attire during Malay ceremonies. Each religion have its own spiritual and mentally practices based on the thought. According to Zubaidah Shawal (1994), every human being

Revised Version Manuscript Received on April 19, 2019.

Arba'iyah binti Ab. Aziz, Faculty of Art \& Design, University Teknologi MARA (UiTM) Malaysia Email: arbaiyah@salam.uitm,edu.my

Mohamad Kamal bin Abd Aziz, Faculty of Art \& Design, University Teknologi MARA (UiTM) Malaysia, Email: mkamal_054@salam.uitm.edu.my

Nabilah binti Mudzafar, Faculty of Art \& Design, University Teknologi MARA (UiTM) Malaysia Email: nabilah933@uitm.edu.my

Nor Idayu binti Ibrahim, Faculty of Art \& Design, University Teknologi MARA (UiTM) Malaysia, Email : idayuibrahimy@gmail.com

need something to cover themselves where clothes is needed of each individual, regardless of status and position. Clothing is required in every activities of life, from the

informal activities to formal ceremony. Each activity tends to have different type of clothing that suit in different occasion. Malay keep preserving and updated their values and tradition. Regard from this, they have invented more beautiful piece of fabric to produce attire of their own identity. Apart from that, each creation have its own significance for specific occasions. This only can be traced out in Malay custom traditions and environments.

Wan Abdul Kadir (2002) has mentioned that the Malay can be categorized into three main components which are practicing the Malay customs, using Malay language and they profess Islam. Malay customs have been practices from century. Its tradition being heir from layers of generation until this moment in time. They still practicing them but some changes occur to align with current lifestyle.

UNESCO (2012) underlies culture as a complex whole which includes knowledge, beliefs, arts, morals, laws, customs, and any other capabilities and habits acquired by a human as a member of society. This definition reflects to a society that have existed in the Malay Archipelago norms. Norms explained as a standard or pattern, especially of social behavior that is typical or extended.

According to Syed Alwi (1962) custom is also explained:

'peraturan atau cara-cara melakukan yang sudah menjadi kebiasaan; adat kebiasaan; resam. Adat berbagai-bagai yang menjadi kebiasaan, majlis rasmi untuk menyambut sesuatu peristiwa, upacara'

It also includes the ways of life and practices from a generation since infant days. This research is focuses on the children ages because they are the pure cultural heirs. The Malay folks have taught their kids from the early age, as in Malay poem said that melentur buluh biarla dari rebungnya. Its show that, the new generations (kids) will follow the lessons they gained regarding custom and traditions and practicing them. The United Nations Convention on the Right of the Child (1989) in it portal have define Child as 'a human being below the age of 18 years unless under the law applicable to the child'. Referring to (Undang-undang Malaysia (reprinted) Akta 611 Akta Kanak-kanak 2001. Children is a human being between the stages of birth and puberty. 
Malaysia Child Act 2001 define children is a person who age is under eighteen years old.

While the Convention on The Rights of the Child (1997) claimed that children means every human being below the age of eighteen years or less. Another clarification as stated by Prof. Datin Nor Aziah Mohd Awal;'secara umumnya di Malaysia kita takrifkan kanak-kanak di bawah umur 18 tahun. Namun mengikut perundangan Islam definisi kanak-kanak adalah untuk lelaki mencapai baligh sementara perempuan adalah keluar haid (boleh hamil)'.

She mentioned; generally in Malaysia, children defined as under the age of eighteen years old. But, by referring back to the Islamic legislation the definition of children is who has reach puberty for boys, while girls is those who are out of menstruation phases, has matured. Children love to explore their surroundings. They are taught through verbally and also practically.

\section{Malay Children custom "Adat Istiadat".}

Malay socio-cultural aspect are rich in their own tradition and custom. Each customs and traditions are distinct from one another, and not all tradition and custom being practices by the royal and the communal. Not all tradition and customs are meant for adult and children, neither boys nor girls. The Malay have manage the pertinent tradition and custom that have different practices to differentiate these two type of cultural manifestation by the royal and the communal. There are list of tradition and custom; Adat especially for the Malay children; Hari cukur kepala dan memberi nama anak; Head Shaving and Naming of the Baby, Adat naik buai / Berendoi; swing ceremony, Adat Memijak tanah, Berkhatam Al-Quran, Berkhatan; Circumcision and Bertindik / Piercing the Ear-Lobe by Alhady (1962), Mohamed (1995). Yet, this research is only focus on three main ceremonies there are; head shaving ceremony / cukur jambul, circumcised / berkhatan, and also baby ear piercing / bertindik.

Head shaving ceremony is one of the ceremony for a newborn baby. This practices is different depend on the parents availability and financial factor. A week after the delivery of the baby, according to Malay tradition a ceremonial kenduri of nasi kunyit (yellow cooked sticky rice) is held after the customary performance of shaving head of the baby and naming him/her, (Alhady, 1962). This ceremony can be held after the 44 day of the childbirth equally with the end of mother berpantang or confinement. In this adat;ceremony, the Malay royal family normally cover their baby with a piece of white cloth / napkin wrap around the baby or bedung and place them on layers of Songket. Head shaving is vital 'sunat' for the newborn. This ceremony held on the seven days of the childbirth. After the ceremony ended, it is advised or disunatkan to donate silver or gold to the poverty if they could afford it. Or else, other option is to contra the weight to the baby hairs with money or valuable items (Mohamed, 1995).

This tradition ceremony, though not nowadays much practiced by modernized Malay those in urban areas, is still widely upheld by the more conservative Malays, especially in the village or rural areas. When the boy is about eight to twelve years old, his parents fix the date for his circumcision ceremony. When the preparation is done for this ceremony, the boy's hair being trimmed 'berandam', dressed in gay and gleaming garments and then seated on a specially made pelamin 'bridal couch' before the gathering of guests, male and female. Furthermore, if the boy to be circumcised has completed learning to recite all the thirty chapter or juzuk of the Holy Quran, the circumcision for khatam Quran will take place after the procession. Circumcision for girls is an age-old Malay practice which is still prevalent today. Malay believe, we made to believe that it is Sunnah to circumcise girls as well (Alhady, 1962).

Last but not least, Adat Bertindik (ear piercing ceremony) is a ceremony that mainly celebrated by the Malay girls. The girls are usually aged between five to ten year olds. Traditionally, the piercing in the customary ceremony, the girls' both ears will be pierced by a sharp tool such as needle with a string. The string is stayed in the hole for a few days. After the healing, the string will be replaced with earrings. During the ceremony, the children are dressed in gorgeous clothes. They usually wear Malay traditional dresses such as Baju Kurung and sarong, Songket sarong or Tenun that appear to be an invaluable tradition.

Furthermore, there is limited numbers of information and exposure in term of children attire for certain custom and tradition in Malay norms for either noble or the culture. This type of research is exclusively found from grounded aspect of Malay culture wisdom through generation. This research is an effort to do in depth on historical background, style, design and material use for the children attires from these three different background and lifestyle of the Malay socio-culture. Thorough observation and documentation for each was based on the aims to explore on the style and the material use in each of these children attires. Final finding of this research will answer all of the enquiries found in this research and benefited to other researcher who have same interest in Malay Sociocultural study and its related areas.

\section{MATERIALS AND METHODS}

This research have collection of pictures from various useful sources. Each of the informants been chosen due to their knowledge, experience and expert in Malay custom and traditions.

\section{A. Research Aim}

This historical research aims is to explore on the style and the material use in each of these children attires. This research discuss the children customary clothes in three main ceremonies that are head shaving ceremony / cukur jambul, circumcised / berkhatan, and also ear piercing / bertindik. This research is basically based on the two type of Malay cultural manifestation found by a Malay scholar. According to Siti Zainon Ismail (2016), there are two level of Malay cultural manifestation which are the 'tradisi agung' and 'tradisi rakyat', also known as the royal and the communal. This cultural manifestation clearly stated that the different heir aren't simply inherited from their tradition. Only the true heirs must keep loyal and practice their customs and traditions fully. 


\section{B. Theory of Style}

In addition, this study applied the theory of style by Mayer Schapiro. The theory is an excerpt from style which refer to the constant elements, qualities, and expressions in the art of an individual or a group or the society. It's applied as in the speaking of a life style or the style of civilization. In this context, style is exemplified in a motive or pattern, on in some directly grasp quality of the work of art that help them to localize and date the work and establish connection between groups of works or between cultures. Style here is a symptomatic trait, like the non-aesthetic features of an artifact by Schapiro (1998).

This study analyzed on the artifact gathered from pictorial sources from royal the album of different states in Malaysia, personal collectors and researcher field works. These collection of pictographs has been analyzed and study based on the Malay customary clothe wear by the children.

Table 1: Flowchart of Research Methodology.

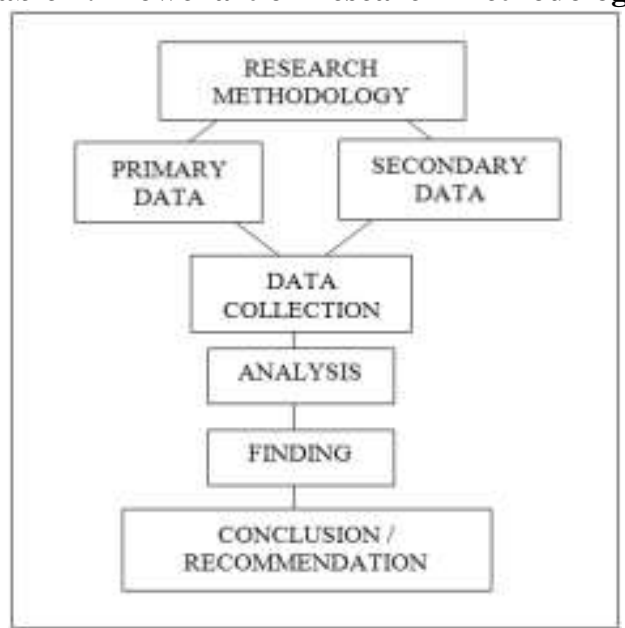

This paper emphasize a flowchart methodology that gained through several steps. These data gather via two type of data collection, its use the primary data and secondary data sources. The second steps, upon gathering more viability source, researcher conduct a verbal interview and discussion with selected informants that are expert in this research field. The open ended questions are discuss with them to gather and to scrutinize more precise information related to this study. All the data were analyze and referred start form the analysis, finding and up to reaching the final step of research conclusion. This is the guide for the researcher to achieve research aim and objective and research question and finalize them all the data collections in a proper appropriate manner.

\section{Research Question}

This method emphasize in answering the research question accordingly. This research question is: What is the specific costume of style and the material use in Malay children attires?

\section{RESULT AND DISCUSSION}

This research pictographs collection are gather from various sources. Interview with correspondent informants, discussion with the experts, archival sources, and personal collections. This research have classified for only three main Malay ceremonies specifically made for the Malay children. This is because, researchers found that, these three main ceremonies are commonly been practice in this period of time for both royal and communal tradition.

Table II: List of research pictographs.

\begin{tabular}{|l|l|}
\hline \multicolumn{1}{|c|}{ The Royal Tradition } & The Communal Tradition \\
\hline Head Shaving Ceremony / Cukur Jambul & \\
\hline $\begin{array}{l}\text { The Johor Royal family during head shaving } \\
\text { ceremony/cukur jambul ceremony; berandam surai } \\
\text { for their grandchildren (2018). }\end{array}$ & $\begin{array}{c}\text { 2. The communal children during the baby head shaving } \\
\text { ceremony (2018). }\end{array}$ \\
\hline
\end{tabular}




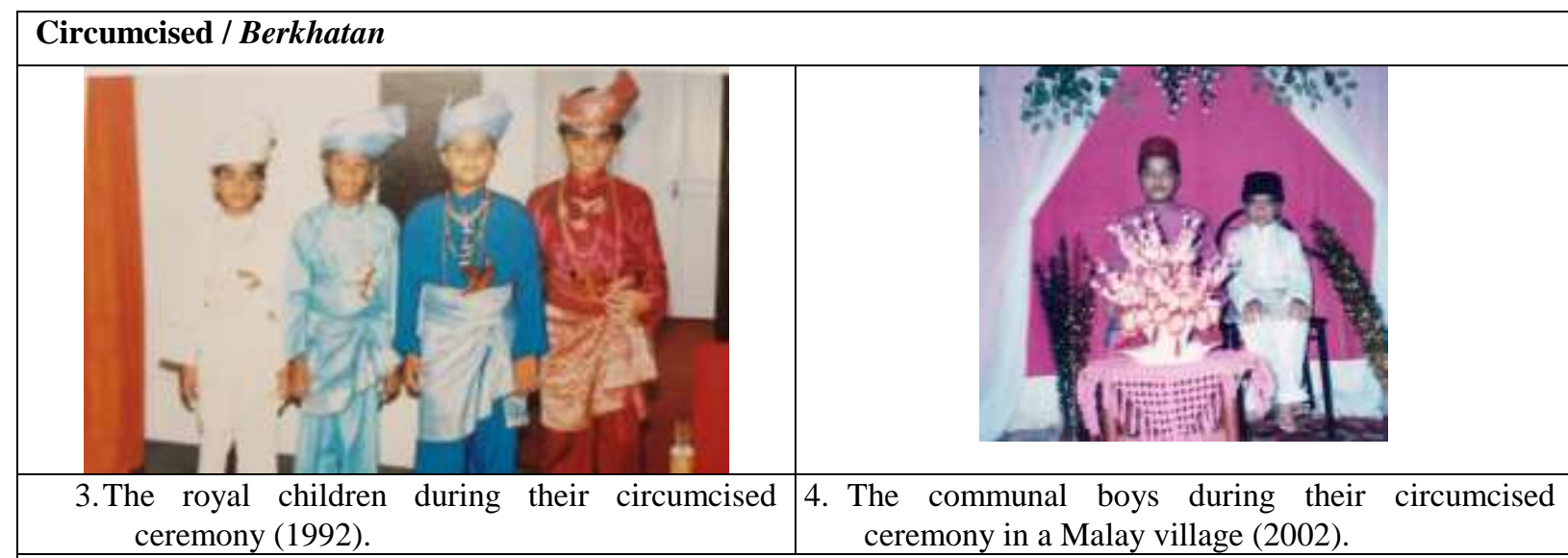

Baby Ear Piercing / Bertindik

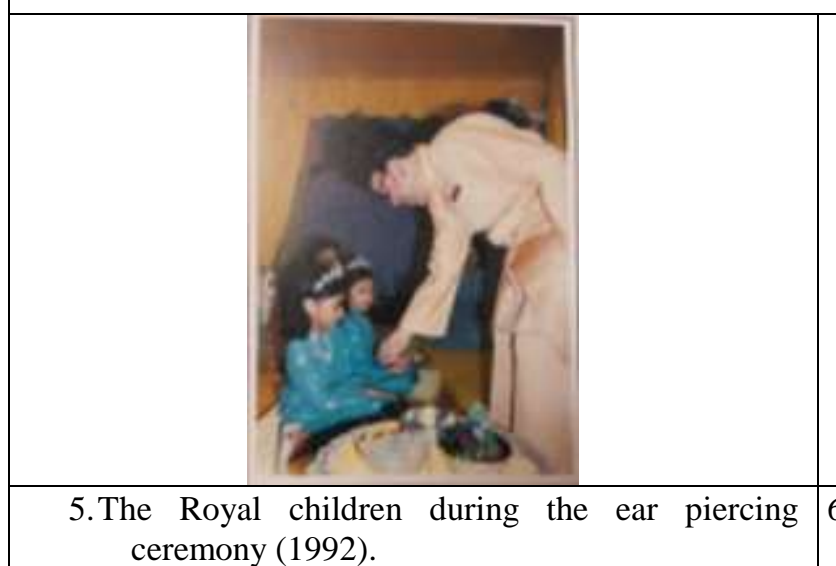

This research have make up to the main point of this research handed. This research have successfully answered the research aim objective and research questions. The first and second picture, shows picture of infant during baby head shaving ceremony/ cukur jambul for the Malay Royal custom and tradition and communal tradition. Malay Royal tradition maintain the uses of songket for most of their ceremonies for both adult and children. They use natural base material such as cotton and silk that can be reproduced to make new songket clothe. Meanwhile the communal, use batik sarong for their children in this ceremony. They wrap the infant in a piece of beautiful color batik, showing the concept of happiness and thankfulness to their God for giving such a beautiful gift; a baby in their family. They tend to use economical fabric that are available in their area.

In Malay custom and tradition, this head shaving; cukur jambul ceremony is an important ceremony that have been practiced from the ancestor ages to symbolize a clean baby from bad or dirty environment physically and spiritually. This ceremony also align with the Islam belief and taught. All of Malay ceremony customs and traditions are based on the teachings of Islam mainly the Al-Qur'an and Hadith.

The third and fourth pictures is the children ceremony of circumcised / berkhatan. This data collection are a collection of children circumcised ceremony specifically for the Royal prince under the age of eighteen years. The royal children are YM Tunku Mohd Alauddin, YM Tunku Nasruan 'Adil, YM Tunku Nasaifuddin, YM Tengku Aslahuddin (photo from; 25 Royal Album, Silver Jubilee Anniversary of the reign of His Royal Highness Tuanku Ja'afar Al-Hak on the throne of Negri Sembilan Darul Khusus) in 1992. The Malay Royal members,
6. The communal children during the ear piercing ceremony (2017).

still maintain using the Malay traditional style of Baju Melayu for berkhatan - circumcised ceremony. The prince wear a specific clothes of Baju Melayu with stand collar call cekak musang. Baju Melayu is a pair of top and long pants in same material and colour. Baju Melayu cekak musang have 5 buttons and three equal size of patch pockets. Its long pants have pocket on its both sides. Their headdress of tengkolok in Negeri Sembilan style, called Dendam Tak Sudah. Their tengkolok songet matching with their samping and bengkung; waist band. The samping are folded in pakai di luar; outer garment style pleated at the left hand side. They also wear other accessories as a complete appearance as a royal family.

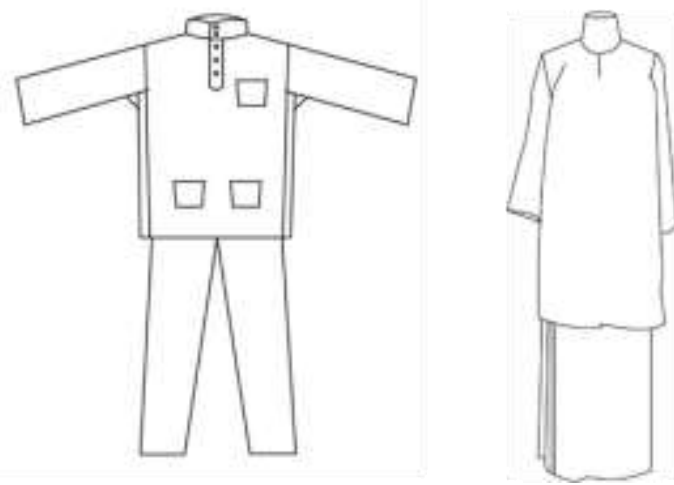

Figure I : Technical Drawing of traditional Malay clothes of Baju Melayu and Baju Kurung. 
Figure 1 is an illustration of technical drawing of the Malay traditional attire of Baju Melayu for the boys and men, meanwhile Baju Kurung for the girls and women. These traditional style of clothing is worn by both the boy and girl during the most of their ceremony and customs. Baju Melayu comes in various styles. In figure 1 , page 8 , this is technical drawing for the traditional Malay attire for boy and girl. The style of Baju Melayu Cekak Musang, a standing collar made for the boys. Other than this style, there is much simpler style which has a single opening at the neckline with a single button and hand embroider finishing; is called Baju Melayu Tulang Belut. It has two patch pockets at the front part.

Beside that, the fourth picture is a picture of Halirul Akbar and his friend sat on a mini dias wearing a pair of Baju Melayu Cekak Musang with a songket samping of ivory colour. Other than that, he also wore a velvet songkok in black colour. While his friend, wore a pair of Baju Melayu Cekak Musang, in dusty pink colour, match with a piece of samping in blue color. He also wore a head accessories of songkok in red velvet color. This photo during his circumcised ceremony / Berkhatan in 2000 in their hometown at Kuala Kangsar, Perak.

The last group of illustration, the fifth and the sixth are the illustrations for specific gender, the girl. This is an ear piercing ceremony / bertindik of HRH Tunku Miratun Madihah and HRH Tengku Asra Jehan blessed by His Royal Highness. Both princesses wore Baju Kurung in royal blue colour. The princesses also wore accessories; a set of diamond tiara and necklace with a pair of shoe. They sat politely on the royal dais to have a blessing from their family members.

The sixth picture, is the scenario of the communal people during the same ceremony. This photo taken by the researchers during their field work in Sultan Alam Shah Museum, Shah Alam, Selangor in 2017. The baby girl wore a set of beautiful Baju Kurung during the ceremony. In communal tradition, the girl is only wearing Baju Kurung made from practical and affordable fabric. The baby's mother hold the baby girl in her arms in supporting her.

In a conclusion, this research argumentation regarding the children customary clothes have lots to be done. It's still need to be scrutinized more seriously, especially in term of children customary clothes for each Malay ceremony or adat, that are focuses on the boys and girls. It is a vital, to maintain Malay cultural heritage; Traditional Malay attire should avoid from extinct in this big world. For instance, the uses of songket is not fully effectively practice in today's especially in Malaysia. This material are not practical in today' lifestyle and climate, but still this material seem to be used in certain occasion for private group.

\section{ACKNOWLEDGMENT}

Our grateful and thanks to appreciation research teammates, Associate Prof. Dr. Arbai'yah binti Ab. Aziz, Dr. Mohamad Kamal bin Abd. Aziz, Nabilah binti Mudzafar, and Nor Idayu binti Ibrahim. Our appreciation to Universiti Teknologi MARA (UiTM, Shah Alam) the Institute of Research Management \& Innovation (IRMI), for Geran Inisiatif Penyeliaan (GIP) 2019, 600-IRMI 5/3/GIP
(043/2019), also to those who have involved directly or indirectly along the way, lot of love for the continuous support and understanding. Also we would like to appreciate the 2nd ICIGAR-2019 Dubai, for the huge opportunity for us to share our love and passion in Malay custom and tradition. Alhamdulillah. We will looking forwards for the upcoming publications. Thank you.

\section{REFERENCES}

1. A. Samad Ahmad (1990). Seni kehidupan dan kemasyarakatan. Melaka: Associated Educational Distributors (M).

2. Abdullah, A. V. (1999). Adat Pusaka Raja-Raja Dan Orang Besar-Besar Negeri Perak Darul Ridzuan. Ipoh: Compass Life Sdn Bhd

3. Adat Bertindik Masyarakat Melayu. Muzium Alam Shah, Shah Alam; 2017.

4. Akta kanak-kanak 2001 Mengandungi segala pindaan hingga 1 Januari 2006 [Internet].

5. Kpwkm.gov.my. 2006 [cited 20 February 2017]. Available from https://www.kpwkm.gov.my/kpwkm/uploads/files/Dokumen/Ak ta/Akta\%20Kanak-Kanak\%202001.pdf

6. Alhady, S. A. (1962). Malay Custom and Tradition. Singapore: Donald Moore Press Ltd.

7.Alwi al-Hadi S. Malay customs and traditions. 1st ed. Singapore: Donald Moore Press; 1962

8.Arba'iyah Ab. Aziz. (2018). Simbolisme dalam motif songket Melayu Terengganu. 1st ed. Kuala Lumpur: Dewan Bahasa dan Pustaka.

9.Aziz D, Wan Ramli W. (1995). Adat dan pantang larang orang Melayu. Shah Alam: Fajar Bakti.

10.Ibrahim A. (1992). Royal album. Kuala Lumpur: The Royal Album Publications Committee Istana Hingap, Seremban, Negri Sembilan Darul Khusus.

11.Mohamed, A. A. (1995). Siri Pengetahuan; Adat dan Pantang Larang Orang Melayu. Shah Alam: Fajar Bakti.

12.Schapiro M. (1994). Theory and philosophy of art: Style, Artist and Society (Selected papers). New York: George Braziller.

13.Siti Zainon Ismail. (2009) Pakaian cara Melayu. 2nd ed. Bangi: Penerbit Universiti Kebangsaan Malaysia

14.Zubaidah Sual. Adat Melayu. Shah Alam; 2017. Personal communication.

\section{AUTHORS PROFILE}

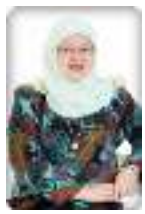

First Author, ASSOC. PROF. DR. ARBA'IYAH BINTI AB AZIZ arbaiyah@salam.uitm.edu.my

Department of Visual Culture Studies, Faculty of Art \& Design, Universiti Teknologi MARA, 40450 Shah Alam, Selangor, Malaysia.

Assoc. Prof. Dr. Arba'iyah Binti Ab Aziz was the Deputy Dean (Academic Affairs) of Universiti Teknologi MARA in 2015-2015. She received her PhD in Malay Culture Management, from the University Malaya in 2010 and MA (Art \& Design Education) from De Montfort University, UK/ UiTM in 1999.

Asso. Prof. Dr. has written extensively on Malay Art and Craft. Among her books are Simbolisme dalam Motif Songket Melayu Terengganu bil 1, (Dewan Bahasa dan Pustaka, Kuala Lumpur, 2018); Batik Merbok Menelusuri Seindah Seni, Semurni Budaya dan Warisan Sepanjang Zaman, (MPH, 2008); Flora, Fauna dan Kosmos Songket (Dewan Bahasa dan Pustaka, 2005); 'KERTUK'(Dewan Bahasa dan Pustaka, 2004). She also contributed her expertise to numbers of publication such as in 'Purba' (Jurnal Persatuan Muzium Negara since 2005; Buletin 
UiTM, Jurnal Wahana Akademik UiTM, Kedah UPENA since 2005; she also an author for the series of Voice of Academia since 2007; Katalog Batik Merbok UiTM Kedah and HPA, role as an author and editor; and also author in INTI jurnal Perintis Pendidikan Fakulti Seni Lukis \& Seni Reka since 2010, she also play major role as an editor in Voice of Academia, Manuscript reviewer in Dewan Bahasa dan Pustaka, and an editor in UPENA. Dr. Arba'iyah's major area of research are the Malay Art and Cultural Management and Textiles. She has successfully supervised numbers of Ph.D and Master Graduates in these area of studies.

Besides that, she also been the internal and external examiner for local and international institution, and conferences. Besides being as an academician Dr. Arba'iyah also serving consultancy for several project by sponsorship institution of UiTM Kedah in 2008 until 2009 and completed numbers of research grant, contracts and projects.

Along of her years serving in UiTM, she received Anugerah Khidmat Cemerlang from UiTM Kedah, 2007, Anugerah Khidmat Cemerlang from UiTM Shah Alam in 2011, 2015 and 2018. In march 31 - April 1, 2009 she received a certificate of Appreciation from Universiti Kebangsaan Malaysia, Ikatan Ahli-Ahli Arkeologi Malaysia, UiTM, 2009, in June 4, 2009 received an Appreciation and Thanks from the Royal Highnest, Dato' Seri Tunku Puteri Intan Safinaz) from Yayasan Sultanah Bahiyah (Dato' Seri Tunku Puteri Intan Safinaz).

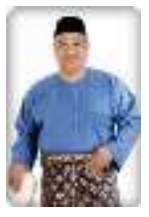

Second Author DR. MOHAMAD KAMAL BIN ABD AZIZ

mkamal054@uitm.edu.my

Department of Visual Culture Studies, Faculty of Art \& Design,

Universiti Teknologi MARA,

Campus Selangor Branch,

42300 Puncak Alam, Selangor, Malaysia.

Dr. Mohamad Kamal bin Abd Aziz is a senior lecturer in Universiti Teknologi MARA since 2008. He received his Ph.D in Art and Culture, from the University Malaya in 2016 and MA (Art \& Design Education) from De Montfort University, UK/ UiTM in 1999. Dr. Kamal is currently a professional membership of MITASA, Alumni UiTM and Alumni UM.

Dr. Mohamad Kamal's major areas of research are the Malay Art and Culture and Modern Malaysian Arts. He has successfully supervised several Ph.D, Master Graduates and Bachelor (Hons.) in these areas of studies. He has written extensively on his major areas of research and other related art critique area of studies. He is the author of Batik Merbok Menelusuri Tradisi Seindah Seni, Semurni Budaya dan Warisan Sepanjang Zaman, (MPH, 2008), he actively write in Dewan Budaya, Dewan Bahasa dan Pustaka since 2002.

In UiTM, besides serving as academician in Faculty of Art \& Design, he also contribute in several Pro Chancellor's speech text for convocation. He had wrote Pro Chancellor's speech text, Tan Sri Arshad Ayub, UiTM 56th Convocation in 2002, Pro Chancellor's speech text YB. Tan Sri Nuraizah binti Abdul Hamid in UiTM 76th Convocation session 6 in 2012 and also Pro Chancellor's speech text YB. Tan Sri Zurainah Anwar in UiTM 89th Convocation session 5 in 2018. Pro Chancellor's speech text UiTM for MoU UiTM, (AD) dengan Universitas Stikubank (UNISBANK) Semarang, Indonesia dan Syara Merdeka, Indonesia pada 16 November 2017 - Canceleri, UiTM Shah Alam. Pro Chancellor's speech text, Tan Seri/ Dato Seri Ibrahim Abu Shah sempena AnDIG 2006.

Besides that, Dr. Kamal also had prepared ministers' speech text. Minister's speech text YB. Dato' Sri Ismail Sabri bin Yaakob Menteri Kemajuan Luar Bandar dan Wilayah sempena Pameran

Load (Leaders of Artists and Designers) FSSR, UiTM, session September 2016 - Januari 2017, on 21st Januari 2017 event. Minister's speech text for Dato Seri Zainuddin Maidin - Menteri Penerangan sempena Pelancaran Projek Batik Merbok di UiTM Kedah in 2007 and also Minister's speech text for Timbalan Menteri Besar Selangor sempena Hari Kualiti UiTM, Shah Alam in 2000.

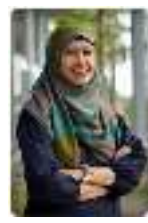

\section{Third Author NABILAH MUDZAFAR} nabilah933@uitm.edu.my Currently Programme Coordinator Department Of Visual Culture Studies Faculty of Art \& Design, Universiti Teknologi MARA,

Campus Selangor Branch,

42300 Puncak Alam, Selangor, Malaysia.

Nabilah Mudzafar received her Master of Mass Communication in UiTM Shah Alam and Bachelor of Fine Art (Hons.) in UiTM Shah Alam. She currently a programme Coordinator in Department of Visual Culture Studies in UiTM. She used to be a Creative / Gallery Executive at Threesixty Art Development Studio.

She is an author for Embedded Visual Schedule Application towards Austistic Children Development: A Preliminary Study (6th International Conference on Engineering Education 2014 (Iceed 2014)). She received a research grant of RAGS Grant title Scaffolded Autistic Mobile Organizer Design Model. Her contribution as a committee member in Projek Asean Art \& Design Symposium and Workshop (Andes) 2016 and as a main Secretariat Art and Design International Conference (AnDIC 2016). Along of her serving with UiTM, she received an Excellent Service Award in 2014.

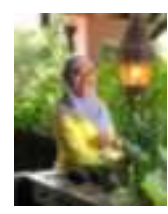

Fourth Author, NOR IDAYU BINTI IBRAHIM

idayuibrahimy@gmail.com

Department of Visual Culture Studies, Faculty of Art \& Design, Universiti Teknologi MARA, 40450 Shah Alam, Selangor, Malaysia.

Born in Malaysia on August 20th, 1992. Currently doing Ph.D, Doctoral Phylosophy in Art and Design in University Technology of MARA, Malaysia. Began passion in exploring the history of arts, world arts, Malay Culture, Malay Archipelago, Malay Custom and Traditions, Malay Royal since my school day and getting more enthusiasm from day to day. Curently, her research are focuses on the Malay traditional Customary Attire for both adult and children age. This research is a part of her academic writing or thesis and been supervise by Asso. Prof. Dr. Arba'iyah Ab Aziz and Dr Mohamad Kamal Abd Aziz.

She has involve in many local and international conference and publication. There are in (2018) Dewan Budaya, Bil 7, 2018, pg 60

Jauhari Jua Mengenal Manikam; (2018) 2nd ICMCR - Singapore 11th - 12th .8.2018, Children Customary Clothe In Malay Head Shaving - Cukur Jambul Ceremony for the Communal. (2018) 2018 ACUADS - Perth

North TAFE 27th - 28th .9.2018, Children Customary Clothe In Malay Head Shaving; Cukur Jambul Ceremony in the Malay Royal Tradition; (2018) ICIGAR 2018 - Jakarta 17th - 18th.11.2018 Hotel santika BSD City-serpong Tangerang, Children Customary Clothe In Malay Ceremonies of Adat Memijak Tanah and Bertindik; Piercing the Ear-Lobe; (2018) AICAD' - deBaron Langkawi 3rd 6th 10.2018, Children Customary Clothe In Malay Circumcise - 
Berkhatan ceremony for the Royal Tradition; (2016) The 4th International Conference for Asia Pacific Arts Studies (ICAPAS) October 18-19th, 2016 Poster Presentation Harper Hotel Mangkabumi, Yogyakarta The Development of Coronation Attire of Seri Paduka Baginda Yang Di-Pertuan Agong from I-XIV starting from 1957 until 2016; (2016) Art \& Design International Conference 2016 (AnDIC 2016)October 9-12th, 2016 Oral Presentation Concorde, Shah Alam \#1570286776 - Scopus Index

The Development of Coronation Attire of Seri Paduka Baginda Yang Di-Pertuan Agong and Seri Paduka Baginda Raja Permaisuri Agong from I-XIV starting from 1957 until 2016; (2016 -

present ), Doctoral Philosophy of Art and Design Universiti Teknologi MARA (UiTM),Shah Alam Dissertation / Thesis The Development of Children Customary Cloth In the Context of Malay Socio-Cultural; (2014-2015) Master of History of Art and Cultural Management Universiti Teknologi MARA (UiTM), Shah Alam. Dissertation / Thesis, The Development of Coronation Attire of Seri Paduka Baginda Yang Di-Pertuan Agong and Seri Paduka Baginda Raja Permaisuri Agong from I-XIV starting from 1957 until 2016; (2012 - 2014) Bachelor of Fashion Design (Hons.) Universiti Teknologi MARA (UiTM), Shah Alam Dissertation / Thesis The Development of Coronation Attire of Duli Yang Maha Mulia Tuanku Sultan dan Permaisuri Perak Darul Ridzuan.; (2012)

Bachelor of Fashion Design (Hons.)Universiti Teknologi MARA (UiTM), Shah Alam Dissertation / Thesis The Mahmeri, Klang;

(2011) Diploma In Art and Design (Fashion Design)

Universiti Teknologi MARA (UiTM), Sri Iskandar, Hair

Comb; (2010) Diploma In Art and Design (Fashion Design)

Universiti Teknologi MARA (UiTM), Sri Iskandar, Voodoo. 